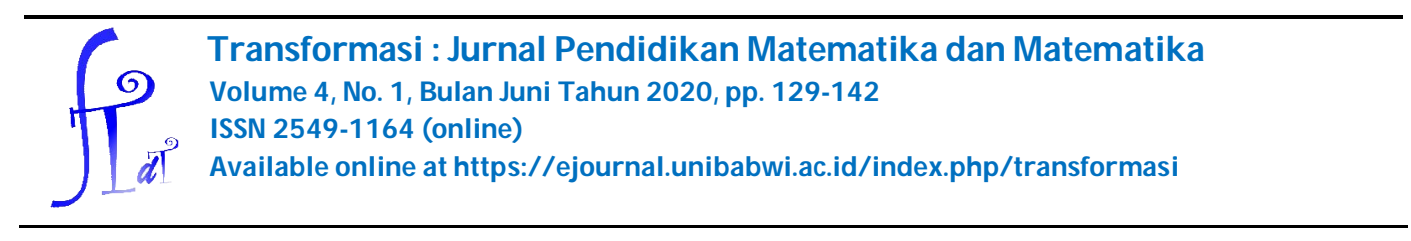

\title{
STRATEGI LEARNING START WITH A QUESTION DAN KEMAMPUAN PEMECAHAN MASALAH MATEMATIS
}

\author{
Rina Rusdiana ${ }^{1}$, lis Holisin ${ }^{2}$, Himmatul Mursyidah ${ }^{3}$ \\ 1,2,3Fakultas Keguruan dan Ilmu Pendidikan, Universitas Muhammadiyah Surabaya \\ Email korespondensi : rinarusdiana793@gmail.com
}

Diterima : 19-02-2020, Revisi: 27-05-2020, Diterbitkan : 25-06-2020

\begin{abstract}
ABSTRAK
Penelitian ini bertujuan untuk mengetahui pengaruh strategi pembelajaran Learning Start with a Question terhadap kemampuan pemecahan masalah matematika siswa. Subjek penelitian ini adalah siswa kelas VII E dan VII F SMP Muhammadiyah 2 Surabaya yang berturut-turut sebagai kelas eksperimen dan kelas kontrol. Masing-masing kelas terdiri dari 22 siswa. Metode penelitian yang digunakan adalah metode kuantitatif dengan instrumen berupa RPP, LKS, soal pretest/ posttest, lembar observasi aktivitas siswa, dan angket respon siswa. Data hasil penelitian diolah dengan uji t dan teknik persentase. Hasil penelitian menunjukkan bahwa: (1) strategi Learning Start with a Question berpengaruh positif terhadap kemampuan pemecahan masalah siswa; (2) aktivitas siswa dominan pada "menyimak dan mampu menyebutkan kembali materi yang telah disampaikan" dengan persentase $50,5 \%$; (3) respon siswa terhadap pembelajaran matematika menggunakan strategi Learning Start with a Question menunjukkan respon positif.

Kata kunci: learning start with a question, kemampuan pemecahan masalah matematika.
\end{abstract}

\begin{abstract}
This study aims to determine the effect of learning start with a Question on students' mathematical problem solving abilities. The subjects of this study were students of class VII E and VII F of Muhammadiyah 2 Junior high school Surabaya as an experimental class and a control class respectively. Each class consist of 22 students. The research method that we used was quantitative method with instruments used were lesson plans, student worksheets, pretest/ posttest questions, observation sheets of student activities, and student response questionnaires. Research data were processed using t-test and percentage technique. The results showed that: (1) the Learning Start with a Question strategy has apositive effect onstudents' mathematical problem solving abilities; (2) student activity is dominant in "listening and being able to recall material that has been submitted" activity with a percentage of $50.5 \%$; (3) student responses to mathematics learning using the Learning Start with a Question strategy are positive.
\end{abstract}

Keywords : learning start with a question Strategies, Problem Solving Skill 


\section{Pendahuluan}

Pendidikan harus dapat mengembangkan siswa ke arah yang positif baik secara intelektual maupun moral (Noor, 2010). Dalam kenyataannya, hal ini masih sulit diperoleh terutama dalam pembelajaran matematika yang membutuhkan kemampuan berpikir tingkat tinggi. Hal tersebut dapat dilihat dari hasil survei Program for International Student Assessment (PISA) tahun 2018 oleh Organization for Economic Cooperation and Development (OECD), dalam bidang matematika Indonesia berada di urutan ke-72 dari 77 negara dengan skor 379 (OCED, 2019). Hal tersebut menunjukkan bahwa kemampuan siswa Indonesia dalam menginterpretasikan dan memecahkan masalah masih sangat rendah (Oktafiana, Holisin, \& Mursyidah, 2019).

Matematika merupakan pelajaran yang dibutuhkan penerapannya dalam kehidupan sehari-hari (Utami, Ainy, \& Mursyidah, 2019). Sehingga perlu untuk memiliki keterampilan tentang bagaimana menyelesaikan masalah matematika dari berbagai ilmu yang telah diperoleh. Pemecahan masalah menjadi bagian dari kurikulum matematika yang sangat penting karena dalam proses pembelajaran serta penyelesaian masalah, siswa dimungkinkan memperoleh pengalaman, menggunakan pengetahuan dan keterampilan yang sudah dimiliki untuk diterapkan pada pemecahan masalah yang bersifat tidak rutin (Afrida \& Handayani, 2018).

Kemampuan pemecahan masalah dapat digunakan sebagai indikator untuk mengukur kemampuan berpikir seseorang karena dengan kemampuan pemecahan masalah yang baik akan mampu menyelesaikan persoalan yang rumit sekalipun. Selain itu, Handayani (2017) menyatakan bahwa siswa yang memiliki kemampuan pemecahan masalah adalah siswa yang memiliki pemahaman yang baik tentang suatu masalah, mampu mengkomunikasikan ide-ide dengan baik, mampu mengambil keputusan, memiliki keterampilan tentang bagaimana mengumpulkan informasi yang relevan, menganalisis dan menyadari betapa perlunya meneliti kembali hasil yang telah diperoleh.

Kemampuan pemecahan masalah siswa dapat ditumbuhkan melalui proses pembelajaran yang baik. Oleh karena itu, guru harus memiliki strategi pembelajaran yang bisa mendorong siswa untuk terlibat secara aktif dalam proses pembelajaran termasuk dalam kegiatan eksplorasi serta mampu menerapkan teori yang 
diajarkan untuk memecahkan masalah matematis yang dihadapi. Selama ini, berdasarkan hasil observasi yang telah dilakukan selama magang karya di SMP Muhammadiyah 2 Surabaya pada tanggal 9 Sepetember sampai 9 November 2019, didapatkan bahwa 65\% siswa masih kesulitan dalam memecahkan suatu masalah. Siswa juga belum bisa memahami soal dan bagaimana cara menyelesaikannya serta mengembangkan solusi dari materi yang sudah disampaikan. Terlebih lagi strategi pembelajaran yang digunakan adalah strategi pembelajaran yang berpusat pada guru sehingga minat siswa untuk belajar masih rendah. Sehingga perlu adanya strategi pembelajaran yang dapat menciptakan pembelajaran yang aktifdan mendukung kemampuan pemecahan masalah siswa. Strategi pembelajaran yang dapat diterapkan adalah dengan strategi Learning Start with a Question.

Strategi Learning Start with a Question merupakan strategi pembelajaran yang dapat membantu siswa untuk mengembangkan kemampuan pemecahan masalah. Learning Start with a Question merupakan salah satu pembelajaran aktif yang memberi kesempatan kepada siswa untuk aktif dalam belajar melalui bertanya (Haryadi \& Nurhayati, 2015). Sedangkan menurut Hamruni (2009) strategi Learning Start with a Question adalah suatu strategi pembelajaran dimana proses belajar sesuatu yang baru akan lebih efektif jika siswa aktif dalam bertanya sebelum mereka mendapatkan penjelasan tentang materi yang akan dipelajari dari guru sebagai pengajar.

Strategi ini mendorong siswa untuk aktif bertanya, dimana siswa perlu membaca bahan ajar terlebih dahulu kemudian membuat pertanyaan dari materi yang belum dipahami. Bertanya dapat dipandang sebagai refleksi dari rasa keingintahuan siswa. Kegiatan bertanya dalam pembelajaran dapat membantu siswa menerima informasi dengan lebih sempurna sehingga dapat mengembangkan kemampuan kognitif dan menuntut siswa untuk berpikir, mengolah informasi yang diterima dan mengaitkannya dengan permasalahan yang ditemui. Bertanya adalah stimulus yang efektif untuk mendorong kemampuan pemecahan masalah siswa. Sehingga kami memilih strategi Learning Start with a Question untuk diterapkan dalam penelitian ini.

Dari uraian diatas, peneliti ingin mengetahui lebih lanjut mengenai pengaruh penerapan strategi Learning Start with a Question terhadap kemampuan pemecahan masalah matematis siswa kelas VII di SMP Muhammadiyah 2 Surabaya. Sebelumnya terdapat beberapa penelitian yang menerapkan strategi Learning 
Start with a Question, tetapi tidak untuk mengetahui pengaruh strategi tersebut terhadap kemampuan pemecahan masalah.salah satunya yaitu penelitian yang dilakukan oleh Ayu Andirawati, dkk. (2013) yang meneliti tentang pengaruh strategi Learning Start with a Question terhadap kemampuan komunikasi matematis siswa. Hasil penelitian menunjukkan kemampuan komunikasi matematis siswamenggunakan strategi Learning Start with a Question lebih baik dari pada menggunakan strategi pembelajaran langsung.

Adapun tujuan penelitian ini adalah: (1) mendeskripsikan ada/ tidaknya pengaruh yang positif dan signifikan penggunaan strategi pembelajaran Learning Start with a Question terhadap kemampuan pemecahan masalah siswa, (2) mendeskripsikan aktivitas siswa selama proses pembelajaran matematika dengan menggunakan strategi Learning Start with a Question, dan (3) mendeskripsikan respon siswa setelah pembelajaran menggunakan strategi Learning Start with a Question.

\section{Metode Penelitian}

Penelitian ini menggunakan metode kuantitatif dengan jenis penelitian eksperimen untuk menunjukkan pengaruh strategi Learning Start with a Question terhadap kemampuan pemecahan masalah matematika siswa. Desain penelitian yang digunakan adalah True Experimental Design. Peneliti tidak membentuk kelompok baru melainkan memilih dan menentukan kelompok yang sudah ada menjadi kelompok eksperimen dan kelompom kontrol yang dipilih secara random. Populasi yang digunakan dalam penelitian ini adalah seluruh siswa SMP Muhammadiyah 2 Surabaya yang terdiri dari 17 kelas. Sampel penelitian terdiri dari siswa kelas VII SMP Muhammadiyah 2 Surabaya sebanyak 44 siswa, dengan 22 siswa kelas VII E sebagai kelas eksperimen dan 22 siswa kelas VII F sebagai kelas kontrol.

Variabel bebas dalam penelitian ini adalah perlakuan yang diberikan pada sampel penelitian yaitu pembelajaran dengan strategi Learning Start with a Question pada kelas eksperimen. Sedangkan variabel terikat adalah kemampuan pemecahan masalah matematika siswa. Instrumen yang digunakan dalam penelitian ini yaitu soal tes, angket observasi dan angket respon siswa. Soal tes berupa soal esai yang terdiri dari 4 soal, soal disusun sesuai dengan indikator kemampuan pemecahan masalah meliputi pemahaman terhadap masalah, membuat model matematika dengan menenukan strategi pemecahan masalah, menyelesaikan masalah, dan memeriksa kembali jawaban yang diperoleh. Angket observasi 
digunakan untuk mengetahui aktivitas siswa selama pembelajaran berlangsung. Kegiatan yang nilai selama observasi yaitu menuliskan informasi yang diperoleh, menentukan bagian materi yang sudah dan belum dipahami, bertukar pendapat, menyusun pertanyaan, serta menyimak dan menyebutkan kembali materi yang telah disampaikan. Sedangkan angket respon siswa digunakan untuk mengetahui respon siswa setelah mengikuti pembelajaran dengan strategi Learning Start with a Question. Angket diberikan pada kelas ekspeimen setelah pembelajaran selesai. Lembar angket berisi pendapat siswa mengenai proses pembelajaran menggunakan strategi Learning Start with a Question.

\section{Prosedur Penelitian}

Penelitian ini dilaksanakan dalam tiga tahap, yaitu:

1. Tahap perencanaan

Dilakukan dengan melakukan permohonan izin kepada pihak sekolah, menyusun dan menetapkan pokok bahasan yang digunakan dalam penelitian, merancang perangkat pembelajaran dan instrumen yang digunakan dalam penelitian meliputi RPP, soal pretest-posttest, lembar observasi aktivitas, dan angket yang kemudian divalidasi dan diuji coba untuk mengetahui validitas, reliabilitas, daya pembeda, dan tingkat kesukaran instrumen. Selanjutnya menentukan kelas eksperimen dan kelas kontrol secara acak.

2. Tahap Pelaksanaan

Dilakukan dengan pemberian pretestpada kelas eksperimen dan kelas kontrol, kemudian menerapkan strategi pembelajaran pada kelas eksperimen dengan langkah-langkah sebagai berikut : (a) guru membagikan bahan ajar kepada siswa yang berisi inti materi dan siswa diminta untuk mempelajari bahan ajar dengan teman sebangku (berpasangan); (b) guru meminta siswa memberi tanda pada bagian bacaaan yang belum dipahami; (c) guru mengabungkan dua pasangan belajar dengan pasangan lainnya agar siswa dapat berdiskusi terkait dengan poin-poin yang belum dipahami, sehingga dapat mendorong siswa untuk berpikir dan mencari solusi dari pertanyaan yang ditemui sebelum ditanyakan kepada guru; (d) guru meminta siswa kembali ke kelompok asal dan siswa menuliskan pertanyaan yang masih belum dipahami setelah berdiskusi; (e) guru mengumpulkan pertanyaan-pertanyaan siswa dan menyampaikan materi pembelajaran dengan menjawab 
pertanyaan-pertanyaan siswa. Sedangkan pada kelas kontrol dilakukan pembelajaran menggunakan strategi yang berpusat pada guru. Kemudian kedua kelas diberikan posttest untuk mengetahui pengaruh strategi pembelajaran Learning Start with a Question terhadap kemampuan pemecahan masalah siswa.

3. Tahap pengolahan dan analisis data

Pada tahapini dilakukan pengolahan data yang sudah diperoleh untuk memperoleh data kemampuan pemecahan masalah siswa serta menyimpulkan hasil penelitian.

\section{Teknik Pengumpulan Data dan Instrumen Penelitian}

Teknik pengumpulan data yang digunakan adalah tes, observasi, dan angket, dengan instrumen yang digunakan berupa soal pretest/ posttest, lembar observasi dan angket respon siswa yang telah divalidasi oleh ahli

\section{Teknik Analisis Data}

Analisis data dilakukan dengan uji normalitas dan homogenitas untuk mengetahui apakah sampel yang diteliti berasal dari populasi yang berdistribusi normal dan homogen atau tidak. Setelah melakukan uji normalitas dan homogenitas kemudian dilakukan uji kesamaan dua rata-rata untuk mengetahui apakah terdapat perbedaan kemampuan pemecahan masalah siswa setelah diberikan perlakuan pada kelas eksperimen. Selain itu juga dilakukan perhitungan nilai N-gain untuk mengetahui besar peningkatan rata-rata nilai pretest dan posttest pada kelas eksperimen dan kelas control. Sedangkan data aktivitas siswa dan respon siswa dianalisi dengan teknik persentase. Adapun untuk data respon siswa diinterpretasi sesuai dengan kriteria interpretasi respon siswa menurut (Holisin, 2019) seperti pada Tabel 1.

Tabel 1. Kriteria Interpretasi Respon Siswa

\begin{tabular}{cc}
\hline Persentase respon siswa & Kriteria respon siswa \\
\hline $0 \%-20 \%$ & sangat lemah \\
\hline $21 \%-40 \%$ & Lemah \\
\hline $41 \%-60 \%$ & Cukup \\
\hline $61 \%-80 \%$ & Baik \\
\hline $81 \%-100 \%$ & sangat baik \\
\hline
\end{tabular}




\section{Hasil dan Pembahasan}

Penelitian yang telah dilakukan mendapatkan hasil data dari pretest dan posttest kemampuan pemecahan masalah matematika siswa. Data pretest dan posttest kelas kontrol dan kelas eksperimen kemudian dianalisis lebih lanjut menggunakan uji normalitas, uji homogenitas dan uji kesamaan dua rata-rata. Dari hasil analisis tahap awal diperoleh hasil uji normalitas kelas eksperimen dan kelas kontrol yang disajikan pada Tabel 2.

Tabel 2.Hasil Uji Kolmogorov Smirnov pada Data Pretest Kelas Eksperimen dan Kelas Kontrol

\section{One-Sample Kolmogorov-Smirnov Test}

\begin{tabular}{lrr}
\hline & Eksperimen & Kontrol \\
\hline $\mathrm{N}$ & 22 & 22 \\
Mean & 49.67 & 51.64 \\
Std. Deviation & 7.208 & 8.079 \\
Absolute & .143 & .125 \\
Kolmogorov-Smirnov Z & .671 & .587 \\
Asymp. Sig. (2-tailed) & .758 & .881 \\
\hline
\end{tabular}

Berdasarkan Tabel 2 diperoleh nilai signifikansi lebih besar dari $\boldsymbol{\alpha}=0,05$. Nilai signifikan kelas eksperimen adalah 0,78 dan nilai signifikansi kelas kontrol adalah 0,881. Selanjutnya pada kelas eksperimen diperoleh $\boldsymbol{K}_{\boldsymbol{t a b e l}}=\mathbf{0 , 2 8 1} \geq$ $\boldsymbol{K} \boldsymbol{s}_{\text {hitung }}=\mathbf{0 , 1 4 3}$ dan pada kelas kontrol $\boldsymbol{K} \boldsymbol{s}_{\text {tabel }}=\mathbf{0 , 2 8 1} \geq \boldsymbol{K} \boldsymbol{s}_{\text {hitung }}=\mathbf{0 , 1 2 5}$. Karena uji normalitas dari nilai pretest kedua kelas memenuhi kriteria pengujian yaitu signifikansi $>$ 0,05 dan $\boldsymbol{K}_{\text {tabel }} \geq \boldsymbol{K} \boldsymbol{s}_{\text {hitung }}$, maka $\boldsymbol{H}_{\mathbf{0}}$ diterima dan dapat disimpulkan bahwa pada analisis tahap awal sampel kelas eksperimen dan kelas kontrol dinyatakan berdistribusi normal.

Setelah sampel dinyatakan berdistribusi normal, kemudian dilakukan uji homogenitas, dan diperoleh homogenitas data pretest kelas eksperimen dan kelas kontrol yang disajikan pada Tabel 3.

Tabel 3. Uji Homogenitas 


\begin{tabular}{rrrr}
\hline Levene Statistic & df1 & df2 & Sig. \\
.189 & 1 & 42 & .666
\end{tabular}

Berdasarkan Tabel 3, dilihat dari hasil pengujian homogeneity variants dengan P-value = signifikansi (Sig) adalah 0,666 karena itu nilai signifikansi P-value $>\alpha$ maka $\boldsymbol{H}_{\mathbf{0}}$ diterima dan dapat disimpulkan bahwa varian kedua kelompok kelas adalah sama (homogen).

Karena sampel berasal dari populasi berdistribusi normal dan homogen, makauntuk menguji kesamaan dua rata-rata menggunakan uji statistik t. Dan diperoleh hasil seperti pada Tabel 4.

Tabel 4. Uji Kesamaan Dua Rata-Rata

Independent Samples Test

\begin{tabular}{ccccccc}
\hline & F & Sig. & T & Df & \multicolumn{2}{c}{ Sig. Mean Difference } \\
(2-tailed) & \\
\hline $\begin{array}{l}\text { Pretest Equal variances } \\
\text { assumed }\end{array}$ & .189 & .666 & -.901 & 42 & .373 & -2.091 \\
$\begin{array}{l}\text { Equal variances } \\
\text { not assumed }\end{array}$ & & & -.901 & 41.550 & .373 & -2.091 \\
\hline
\end{tabular}

Berdasarkan uji perbedaan dua rata-rata (uji t) didapatkan bahwa $\boldsymbol{t}_{\text {tabel }}=2,01808>\boldsymbol{t}_{\text {hitung }}=-0,901$ maka dapat disimpulkan bahwa tidak terdapat perbedaan kemampuan awal kemampuan pemecahan masalah siswa antara kelas eksperimen dan kelas kontrol.

Selanjutnya pada analisis tahap akhir dari data posttest diperoleh hasil uji normalitas kelas eksperimen dan kelas kontrol yang disajikan pada Tabel 5.

Tabel 5. Hasil Uji Kolmogorov Smirnov pada Data Posttest Kelas Eksperimen dan Kelas

Kontrol

\begin{tabular}{lrr}
\multicolumn{3}{c}{ One-Sample Kolmogorov-Smirnov Test } \\
\hline $\mathrm{N}$ & Eksperimen & Kontrol \\
$\mathrm{Mean}$ & 22 & 22 \\
Std. Deviation & 76.51 & 69.25 \\
Absolute & 9.649 & 10.647 \\
Kolmogorov-Smirnov Z & .111 & .137 \\
Asymp. Sig. (2-tailed) & .520 & .643 \\
\hline
\end{tabular}

Dari Tabel 5 diperoleh nilai signifikan kelas eksperimen adalah 0,950 dan kelas kontrol adalah 0,803. Nilai signifikan data posttest kelas eksperimen dan kelas 
kontrol tersebut lebih dari 0,05, maka $\mathrm{H}_{0}$ diterima. Selanjutnya karena pada kelas eksperimen $K s_{\text {tabel }}=0,281 \geq K s_{\text {hitung }}=0,111$ dan pada kelas kontrol $K s_{\text {tabel }}=0,281 \geq K s_{\text {hitung }}=0,137$, maka dapat disimpulkan bahwa sampel kelas eksperimen dan kelas kontrol dinyatakan berdistribusi normal. Setelah sampel data posttest kelas eksperimen dan kelas kontrol telah dinyatakan berdistribusi normal, kemudian dilakukan uji homogenitas. Berdasarkan hasil perhitungan diperoleh hasil seperti pada Tabel 6 .

Tabel 6. Uji homogenitas

Test of Homogeneity of Variances

\begin{tabular}{rrrr}
\hline Levene Statistic & df1 & df2 & Sig. \\
\hline .118 & 1 & 42 & .733 \\
\hline
\end{tabular}

Dari Tabel 6 diperoleh P-value = signifikansi (Sig) adalah 0,733 oleh karena itu nilai signifikansi P-value $>\alpha$ maka $\boldsymbol{H}_{\mathbf{0}}$ diterimasehingga dapat disimpulkan bahwa varian kedua kelompok kelas adalah samadan sampel dinyatakan homogen.

Setelah sampel dinyatakan berdistribusi normal dan homogen, kemudian dilakukan uji kesamaan dua rata-rata dan diperoleh hasil seperti pada Tabel 7.

Tabel 7. Uji Kesamaan Dua Rata-Rata

Independent Samples Test

\begin{tabular}{|c|c|c|c|c|c|c|c|}
\hline & & $\mathbf{F}$ & Sig. & $\mathbf{T}$ & & $\begin{array}{r}\text { Sig. } \\
\text { f (2-tailed) }\end{array}$ & $\begin{array}{r}\text { Mean Dif- } \\
\text { ference }\end{array}$ \\
\hline \multirow[t]{2}{*}{ Posttest } & $\begin{array}{l}\text { Equal variances } \\
\text { assumed }\end{array}$ & .118 & .733 & 2.371 & 42 & .022 & 7.273 \\
\hline & $\begin{array}{l}\text { Equal variances } \\
\text { not assumed }\end{array}$ & & & 2.371 & 41.632 & .022 & 7.273 \\
\hline
\end{tabular}

Berdasarkan uji perbedaan kedua rata-rata (uji t) didapatkan bahwa $\boldsymbol{t}_{\text {tabel }}=2,01808<\boldsymbol{t}_{\text {hitung }}=2,371$ dan nilai signifikansi $<0,05(0,022<0,05)$ maka $\boldsymbol{H}_{\mathbf{0}}$ ditolak. Hal ini menunjukkan bahwa terdapat perbedaan kemampuan pemecahan masalah siswa antara kelas eksperimen dan kelas kontrol. Sehingga dapat disimpulkan bahwa terdapat pengaruh yang signifikan strategi Learning Start with a Question terhadap kemampuan pemecahan masalah matematika siswa.

Setelah diketahui terdapat pengaruh yang signifikan antara kelas kontrol dan kelas eksperimen melalui uji t, maka dilakukan perhitungan $\mathrm{N}$-gain untuk memberikan gambaran secara umum bagaimana peningkatan kemampuan pemecahan masalah siswa pada kelas kontrol dan kelas eksperimen sebelum dan 
sesedah diberikan perlakuan yang disajikan pada Tabel 8.

Tabel 8. Rekapitulasi Data Kemampuan Pemecahan Masalah Matematika Sebelum dan Sesudah Eksperimen

\begin{tabular}{ccccccc}
\hline & \multicolumn{3}{c}{ Eksperimen } & \multicolumn{3}{c}{ Kontrol } \\
\cline { 2 - 7 } & Pretest & Posttest & & Pretest & Posttest \\
\hline $\bar{X}$ & 49,67 & 76,51 & 0,78 & 51,64 & 69,25 & 0,54 \\
& & & $(\mathrm{~N}-$ gain $)$ & & & $(\mathrm{N}-$ gain $)$ \\
$S D$ & 7,20 & 9,65 & 2,45 & 8,08 & 10,64 & 2,56 \\
Varian & 51,95 & 93,11 & 41,16 & 65,27 & 113,35 & 48,08 \\
\hline
\end{tabular}

Berdasarkan Tabel 8, nilai N-gain kelas eksperimen lebih besar daripada kelas kontrol, hal ini menunjukkan bahwa peningkatan kemampuan pemecahan masalah matematika siswa pada kelas eksperimen lebih tinggi daripada kelas kontrol. Sehinga dapat disimpulkan bahwa strategi Learning Start with a Question berpengaruh positif terhadap kemampuan pemecahan masalah matematika siswa.

Selama pembelajaran berlangsung, dilakukan pengamatan terhadap akivitas siswa yang telah disesuaikan dengan Rencana Pelaksanaan Pembelajaran (RPP). Pengamatan aktivitas siswa diamati oleh observer setiap 5 menit sekali selama 80 menit. Dari hasil pengamatan diperoleh hasil persentase aktivitas siswa seperti pada Tabel 9.

Tabel 9. Hasil Persentase Aktivitas Siswa

\begin{tabular}{clccc}
\hline \multirow{2}{*}{ Kode } & \multicolumn{1}{c}{ Aktivitas Siswa } & \multicolumn{2}{c}{ Petemuan Ke- } & \multirow{2}{*}{ Rata-Rata } \\
\cline { 2 - 3 } & \multicolumn{1}{c}{$\mathbf{1}$} & $\mathbf{2}$ & \\
\hline 1 & $\begin{array}{l}\text { Mampu menuliskan informasi yang diperoleh } \\
\text { setelah membaca bahan ajar }\end{array}$ & $12,2 \%$ & $15,6 \%$ & $13,9 \%$ \\
\hline 2 & $\begin{array}{l}\text { Mampu menentukan bagian materi yang su- } \\
\text { dah dan belum dipahami dengan memberi }\end{array}$ & $10,2 \%$ & $11,4 \%$ & $10,8 \%$ \\
& $\begin{array}{l}\text { tanda pada bagian yang belum dipahami } \\
\text { Mampu bertukar pendapat tentang poin-poin }\end{array}$ & $14,2 \%$ & $14,2 \%$ & $14,2 \%$ \\
\hline 4 & $\begin{array}{l}\text { yang belum dipahami } \\
\text { Mampu menyusun pertanyaan tentang hal }\end{array}$ & $11,6 \%$ & $8,8 \%$ & $10,2 \%$ \\
\hline 5 & $\begin{array}{l}\text { Menyimak dan mampu menyebutkan kemba- } \\
\text { li materi yang telah disampaikan }\end{array}$ & $51,7 \%$ & $50 \%$ & $50,5 \%$ \\
\hline
\end{tabular}

Berdasarkan Tabel 9, terlihat bahwa aktivitas peserta didik yang dominan dilakukan adalah aktivitas "menyimak dan mampu menyebutkan kembali materi yang telah disampaikan" dengan persentase 50,5\%. Aktivitas dominan yang kedua yaitu pada aktivitas "mampu bertukar pendapat tentang poin-poin yang belum di- 
pahami". Sehingga terlihat bahwa penyelesaian masalah dilakukan dengan cara berdiskusi dengan kelompoknya. Hal ini sejalan dengan pendapat Wahyuni (2019) yang menyatakan bahwa interaksi belajar mengajar dapat meningkatkan aktivitas siswa. Sedangkan aktivitas peserta didik yang paling minim dilakukan adalah aktivitas "mampu menyusun pertanyaan tentang hal yang belum dipahami" dengan persentase 10,2\%. Ini menunjukkan bahwa diskusi yang dilakukan oleh siswa dengan kelompoknya membuat mereka lebih paham tentang masalah yang disampaikan, sehingga aktivitas menyusun pertanyaan tentang hal yang belum dipahamisangat sedikit dilakukan.

Hasil angket respon siswa seperti pada Tabel 10, diperoleh bahwa 95\% siswa memberikan respon positif terhadap pembelajaran matematika menggunakan strategi Learning Start with a Question dengan rata-rata persentase siswa yang sangat setuju adalah $43 \%$ dan yang memilih setuju adalah $52 \%$. Ini berarti bahwa respon siswa pada kelas ekperimen terhadap pembelajaran matematika menggunakan strategi Learning Start with a Question dilihat dari kriteria interpretasi respon siswa pada Tabel 1 termasuk dalam kriteria sangat baik. Respon yang baik menunjukkan bahwa siswa senang dengan pembelajaran yang dilakukan (Susanti, 2008).

Tabel 10. Persentase Respon Siswa

\begin{tabular}{|c|c|c|c|c|c|}
\hline \multirow{2}{*}{ No } & \multirow{2}{*}{ Pernyataan } & \multicolumn{4}{|c|}{ Jawaban } \\
\hline & & SS & $\mathbf{S}$ & TS & STS \\
\hline \multirow[t]{2}{*}{1.} & Pembelajaran matematika dengan strategi & 7 & 15 & & \\
\hline & $\begin{array}{l}\text { Learning Start with a Question membuat saya } \\
\text { senang terhadap pembelajaran matematika }\end{array}$ & $32 \%$ & $68 \%$ & $0 \%$ & $0 \%$ \\
\hline \multirow[t]{2}{*}{2.} & Pembelajaran matematika dengan strategi & 10 & 8 & 4 & \\
\hline & $\begin{array}{l}\text { Learning Start with a Questionberbeda dengan } \\
\text { pembelajaran matematika yang biasa dilakukan }\end{array}$ & $45 \%$ & $36 \%$ & $18 \%$ & $0 \%$ \\
\hline \multirow[t]{2}{*}{3.} & Pembelajaran dengan strategi Learning Start & 7 & 13 & 1 & 1 \\
\hline & $\begin{array}{l}\text { with a Questionmemudahkan saya untuk } \\
\text { memahami materi yang disampaikan }\end{array}$ & $32 \%$ & $59 \%$ & $5 \%$ & $5 \%$ \\
\hline \multirow[t]{2}{*}{4.} & Belajar matematikamenggunakan strategi & 9 & 11 & 2 & \\
\hline & $\begin{array}{l}\text { Learning Start with a Question membuat materi } \\
\text { mudah diingat }\end{array}$ & $41 \%$ & $50 \%$ & $9 \%$ & $0 \%$ \\
\hline 5. & Saya senang dengan pembelajaran matematika & 14 & 7 & 1 & \\
\hline
\end{tabular}




\begin{tabular}{|c|c|c|c|c|c|}
\hline & $\begin{array}{l}\text { menggunakan strategi Learning Start with a } \\
\text { Question karena saya dapat berdiskusi dengan } \\
\text { teman }\end{array}$ & $64 \%$ & $32 \%$ & $5 \%$ & $0 \%$ \\
\hline \multirow[t]{2}{*}{6.} & \multirow{2}{*}{$\begin{array}{l}\text { Pembelajaran matematika dengan strategi } \\
\text { Learning Start with a Question bermanfaat bagi } \\
\text { saya }\end{array}$} & 11 & 11 & & \\
\hline & & $50 \%$ & $50 \%$ & $0 \%$ & $0 \%$ \\
\hline \multirow[t]{2}{*}{7.} & \multirow{2}{*}{$\begin{array}{l}\text { Belajar matematika menggunakan strategi } \\
\text { Learning Start with a Question membuat saya } \\
\text { lebih termotivasi }\end{array}$} & 6 & 15 & & 1 \\
\hline & & $27 \%$ & $68 \%$ & $0 \%$ & $5 \%$ \\
\hline \multirow[t]{3}{*}{8.} & Belajar matematika menggunakan strategi & 11 & 11 & & \\
\hline & $\begin{array}{l}\text { Learning Start with a Question membuat saya } \\
\text { lebih aktif dalam belajar }\end{array}$ & $50 \%$ & $50 \%$ & $0 \%$ & $0 \%$ \\
\hline & RATA-RATA & $43 \%$ & $52 \%$ & $5 \%$ & $1 \%$ \\
\hline
\end{tabular}

\section{Kesimpulan}

Berdasarkan hasil penelitian yang telah dilakukan mengenai pengaruh strategi Learning Start with a Question terhadap kemampuan pemecahan masalah matematika siswa kelas VII SMP Muhammadiyah 2 Surabaya, diperoleh beberapa kesimpulan sebagai berikut:

1. Berdasarkan hasil uji t diperoleh bahwa $t_{\text {tabel }}=2,01808 \leq t_{\text {hitung }}=2,371$ sehingga $H_{0}$ ditolak dan $H_{1}$ diterima, ini menunjukkan bahwa terdapat perbedaan nilai rata-rata antara kelas eksperimen dan kontrol sehingga strategi Learning Start with a Question berpengaruh terhadap kemampuan pemecahan masalah siswa. Dan dari uji N-gain dketahui bahwa peningkatan kemampuan pemecahan masalah siswa pada kelas eksperimen lebih tinggi dari pada kelas kontrol yaitu sebesar 0,78 pada kelas eksperimen dan 0,54 pada kelas kontrol. Hal tersebut menunjukkan bahwa strategi Learning Start with a Question berpengaruh positif terhadap kemampuan pemecahan masalah siswa.

2. Aktivitas siswa kelas eksperimen pada saat pembelajaran menggunakan strategi Learning Start with a Question berdasarkan analisis data aktivitas peserta didik, dapat disimpulkan bahwa aktivitas peserta didik yang dominan dilakukan adalah aktivitas "menyimak dan mampu menyebutkan kembali materi yang telah disampaikan" dengan persentase $50,5 \%$. Sedangkan aktivitas peserta didik yang paling minim dilakukan adalah aktivitas "mampu 
menyusun pertanyaan tentang hal yang belum dipahami” dengan persentase $10,2 \%$.

3. Respon siswa terhadap pembelajaran matematika menggunakan strategi Learning Start with a Question sangat baik. Hal ini dilihat dari persentase respon siswa yang menyatakan setuju dan sangat setuju sebesar 95\% dan termasuk dalam kategori sangat baik.

\section{Ucapan Terimakasih}

Peneliti mengucapkan terimakasih kepada kepala dan guru matematika SMP Muhammadiyah 2 Surabaya yang telah memberi dukungan dalam proses penelitian. Serta berbagai pihak yang telah membantu dalam penelitian ini.

\section{Daftar Pustaka}

Afrida, A. N., \& Handayani, S. (2018). Meningkatkan Kemampuan Pemecahan Masalah Matematika dan Rasa Ingin Tahu Siswa Kelas XI Melalui Model ARIAS. PRISMA, 1(1), 33-39.

Hamruni. (2009). Strategi dan Model-model Pembelajaran Aktif Menyenangkan. Yogyakarta: Fakultas Tarbiyah UIN Sunan Kalijaga.

Handayani, D. (2017). Pengaruh Model Problem Based Learning Terhadap Kemampuan Pemecahan Masalah Matematis Siswa di Kelas VIII MTs. S Al-Washliyah Tahun Ajaran 2016-2017. Sumatra utara: Universitas Islam Negri Sumatra Utara.

Haryadi, D. N., \& Nurhayati, S. (2015). Penerapan Model Learning Start with a Question Berpendekatan ICARE pada Hasil belajar. Jurnal Inovasi Pendidikan Kimia, 9(2), 1528-1537.

Holisin, I. (2019, Juni). Pengembangan Model Pembelajaran OSCAR untuk Melatih Penalaran Siswa Sekolah Dasar dalam Menyelesaikan Masalah Matematika. FIBONACCI: Jurnal Pendidikan Matematika dan Matematika, 5(1), 1-10.

Noor, I. (2010). Ke Arah Pendidikan Nilai yang Efektif, Evaluasi dan Memperkuat Dimensi Pendidikan Nilai. Dinamika Ilmu: Journal of Education, 10(2), 1-9.

OCED. (2019). PISA 2018 Result (Volume I, II \& III): Combined Executive Summaries. Paris: OECD Publishing.

Oktafiana, L., Holisin, I., \& Mursyidah, H. (2019). Analisis Soal Matematika Tipe Higher Order Thinking Skills (HOTS) Tingkat SMP. JP3M: Jurnal Pemikiran dan Penelitian Pendidikan Matematika, 2(2), 112-129. 
Susanti, E. (2008). Upaya Peningkatan Respon Siswa Pada Pembelajaran Matematika Melalui Pendekatan Kooperatif Tipe Think Pair Share (TPS). Surakarta: Universitas Muhammadiyah Surakarta.

Utami, F., Ainy, C., \& Mursyidah, H. (2019). Efektivitas Penerapan Model Pembelajaran Creative Problem Solving (CPS) terhadap Hasil Belajar Siswa pada Materi Luas Permukaan Bangun Ruang Sisi Datar. Jurnal Math Educator Nusantara (JMEN), 5(1), 1-13.

Wahyuni, D. S. (2019). Meningkatkan Hasil Belajar Siswa Kelas VIII Dalam Pembelajaran Matematika Melalui Model Pembelajaran Kooperatif Time Token Dengan Media Paper Circle. Surabaya: Universitas Muhammadiyah Surabaya. 